\title{
Pengaruh jarak nozzle penyemprot terhadap kemampukerasan baja komersil dengan metode jominy test
}

\author{
Yusuf1 $^{*}$, Asep Ruchiyat ${ }^{2}$, Muh Anhar ${ }^{3}$ \\ 1,2,3Prodi Perawatan dan Perbaikan Mesin, Politeknik Negeri Ketapang \\ Jl. Rangga Sentap-Dalong, Kelurahan Sukaharja, Kecamatan Delta Pawan, Kabupaten \\ Ketapang-Kalimantan Barat \\ *Corresponding author: yusuf@politap.ac.id
}

\begin{abstract}
Steel is the material most widely used in the industry. To avoid wear and tear on steel, it is necessary to do heat treatment to improve the mechanical properties of the steel according to its application in the field. The increase in hardenability in metals can be determined by doing a hardenability test, namely the Jominy test method. The Jominy test is a method to determine the hardness value of metal using ASTM standards. This research was conducted with varying the distance of the nozzle of the sprayer to the lower end of the specimen, namely $10 \mathrm{~mm}, 12.5 \mathrm{~mm}$, and $14 \mathrm{~mm}$ with a long spraying time of 15 minutes. The heat treatment process at temperature of $780^{\circ} \mathrm{C}$ and 90 minutes holding time. The average hardness value of specimen number one (10 mm spraying distance) is $45.43 \mathrm{kgf}$, specimen number two (12.5 mm spraying distance) is $45.68 \mathrm{kgf}$, and specimen number three $(14 \mathrm{~mm}$ spraying distance) is $44.31 \mathrm{kgf}$. The highest hardness value was specimen number two, there was an increase of $1.87 \mathrm{kgf}(4.02 \%)$, according to ASTM standards where the spraying distance was $12.5 \mathrm{~mm}$.
\end{abstract}

Keywords: Steel, spraying distance, Jominy test.

\begin{abstract}
Abstrak
Baja merupakan material yang paling banyak digunakan di industri. Untuk menghindari terjadinya keausan pada baja, perlu dilakukan heat treatment untuk memperbaiki sifat mekanik dari baja tersebut sesuai dengan aplikasinya dilapangan. Peningkatan kemampukerasan pada logam dapat diketahui dengan dilakukan pengujian hardenability yaitu dengan metode Jominy test. Uji Jominy merupakan sebuah metode untuk mengetahui nilai kemampukerasan logam menggunakan standar ASTM. Penelitian ini dilakukan dengan memvariasikan jarak nozzle penyemprot terhadap ujung bagian bawah spesimen yaitu 10 $\mathrm{mm}, 12.5 \mathrm{~mm}$, dan $14 \mathrm{~mm}$ dengan lama waktu penyemprotan selama 15 menit. Proses heat treatment dilakukan pada temperatur $780{ }^{\circ} \mathrm{C}$ dengan holding time 90 menit. Nilai kemampukerasan rata-rata spesimen satu dengan jarak penyemprotan $10 \mathrm{~mm}$ yaitu $45.43 \mathrm{kgf}$, spesimen dua dengan jarak penyemprotan $12.5 \mathrm{~mm}$ yaitu 45,68 $\mathrm{kgf}$ dan spesimen tiga dengan jarak penyemprotan $14 \mathrm{~mm}$ yaitu $44.31 \mathrm{kgf}$. Nilai kekerasan tertinggi yaitu pada spesimen dua terjadi peningkatan sebesar $1.87 \mathrm{kgf}$ (4.02\%), sesuai standar ASTM dimana jarak penyemprotan adalah $12.5 \mathrm{~mm}$.
\end{abstract}

Kata kunci: Baja, Jarak Penyemprotan, Jominy Test.

\section{Pendahuluan}

Pada perkembangan teknologi saat ini, khususnya dibidang teknik mesin lebih dominan memerlukan bahan yang terbuat dari logam dan paduannya. Penggunaan bahan dalam perkembangan teknologi maju memerlukan bahan yang memiliki sifat kekuatan yang tinggi. Kekuatan bahan dihubungkan dengan sifat mekanik dari bahan tersebut seperti kekuatan (strength), kekerasan (hardness), dan kekenyalan (elasticity). Untuk mengetahui sifat dari 
logam maka perlu dilakukan pengujian yang sesuai dengan standar yang ditentukan, kemudian diambil kesimpulan tentang sifat mekanis dari logam tersebut.

Sifat kekerasan (hardness) suatu logam merupakan salah satu persyaratan utama di dalam pemilihan suatu elemen mesin. Kekerasan suatu logam, baja khususnya, dapat dimodifikasi tanpa menambahkan unsur paduan dan dilakukan dengan perlakuan panas. Kemampukerasan (hardenability) adalah kemampuan suatu material untuk dapat dikeraskan sampai kedalaman tertentu dengan cara perlakuan panas (heat treatment) dengan properti mekanik, hingga terbentuk martensite pada proses pendinginan untuk mencapai kekerasan tertentu. Hardening merupakan perlakuan panas untuk mendapatkan kekerasan pada material baja.

Perlu dibedakan antara pengertian kekerasan dan kemampukerasan (hardenability). Kekerasan adalah ukuran dari pada daya tahan terhadap deformasi plastik. Sedangkan kemampukerasan adalah kemampuan bahan untuk dikeraskan. Tidak semua material mampu dikeraskan dengan cara tersebut, untuk mengetahuinya perlu dilakukan uji hardenability.

\section{Tinjauan Pustaka}

Baja adalah paduan besi-karbon, dengan kandungan karbon tidak lebih dari $2 \%$. Baja merupakan material yang paling banyak digunakan sebagai bahan industri, karena sifat-sifat dari baja bervariasi, mulai dari paling lunak sampai yang paling keras, tergantung dari besarnya kandungan karbon, semakin besar kandungan karbon maka akan semakin rapuh atau getas. Pada pengaplikasiannya baja-baja tersebut dapat menerima beban dari luar, baik beban tekan, beban geser, beban puntir dan beban gesek yang akan menyebabkan terjadinya keausan pada baja [1,2]. Baja komersial adalah jenis konstruksi baja yang mudah ditemui di pasaran. Baja ini merupakan baja karbon rendah dengan kadar karbon sampai $0.30 \%$, sangat luas pemakaiannya sebagai baja konstruksi umum, untuk baja profil rangka bangunan, baja tulangan beton, rangka kendaraan, mur, baut, pelat, pipa, dll. [10]. Strukturnya terdiri dari ferrite dan sedikit pearlite, sehingga baja ini kekuatannya relatif rendah, lunak namun keuletannya tinggi, mudah dibentuk dan di-machining.

Untuk mengatasi keausan pada baja, maka perlu dilakukan heat treatment untuk memperbaiki sifat mekanik dari baja yang sesuai dengan aplikasinya di lapangan. Nilai kekerasan yang dapat dicapai tergantung pada kadar karbon dalam baja, temperatur pemanasan, dan holding time, serta laju pendinginan yang dilakukan. Perlakuan panas pada baja memegang peranan penting dalam upaya meningkatkan kekerasan baja sesuai dengan kebutuhan [3].

Mampu keras tidak dikaitkan dengan kekerasan maksimum yang dapat dicapai oleh baja. Kekerasan permukaan baja tergantung pada prosentase unsurunsur paduan, besar butir austenite, temperatur austenisasi, lama pemanasan, laju proses pendinginan serta struktur mikro baja sebelum dikeraskan. Kekerasan suatu logam, khususnya baja dapat dimodifikasi tanpa menambahkan unsur paduan dan dilakukan dengan perlakuan panas. Sifat kekerasan suatu logam merupakan salah satu persyaratan utama dalam pemilihan suatu elemen mesin [4].

Tidak semua material mampu dikeraskan dengan cara tersebut, untuk mengetahuinya perlu dilakukan uji hardenability (pengujian untuk mengetahui kemampukerasan suatu logam). Salah satu metode pengujian hardenability yaitu Jominy test (uji jominy). Uji jominy merupakan sebuah metode untuk mengetahui kemampuankerasan logam (baja) [5]. Caranya yaitu benda uji dipanaskan pada suhu yang ditentukan, kemudian didinginkan dengan menyemprotkan air pada salah satu ujungnya (bagian bawah). Setelah pengujian dengan alat uji jominy, diukur 
kekerasannya dengan menggunakan alat uji kekerasan $[6,7]$.

\section{Metode Penelitian}

Penelitian ini dilakukan dengan eksperimen, dalam metode ini hal yang dilakukan adalah mengamati perubahan nilai kemampukerasan material baka komersil setelah dilakukan heat treatment dengan proses pendinginan cepat menggunakan alat uji jominy. Tahapannya adalah pembuatan spesimen, proses pemanasan pada tungku pemanas, proses pendinginan menggunakan alat uji jominy, dan tahap terakhir adalah melakukan pengujian kekerasan dari material menggunakan alat uji tekan.

Adapun spesimen uji menurut standar ASTM, berupa sepotong baja silinder dengan ukuran panjang $100 \mathrm{~mm}$, diameter $25 \mathrm{~mm}$ dan tinggi pancaran air dari ujung nosel adalah $65 \mathrm{~mm}$. Bentuk spesimen dan proses quencing dapat dilihat pada Gambar 1, sedangkan perlakuan pada masing-masing spesimen disajikan pada Tabel 1.

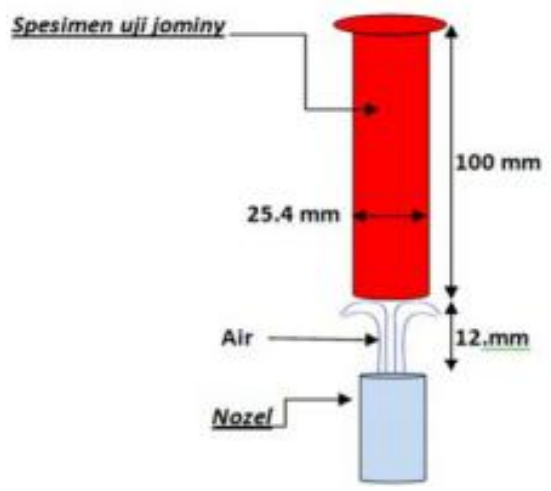

Gambar 1. Spesimen Uji Jominy [8]

Tabel 1. Perlakuan pada masing-masing spesimen

\begin{tabular}{cccc}
\hline $\begin{array}{c}\text { Spesimen } \\
\text { no. }\end{array}$ & $\begin{array}{c}\text { Temperatur } \\
\left({ }^{\circ} \mathrm{C}\right)\end{array}$ & $\begin{array}{c}\text { Nozzle } \\
\text { distance } \\
(\mathrm{mm})\end{array}$ & $\begin{array}{c}\text { Qunching } \\
\text { time }(\mathrm{s})\end{array}$ \\
\hline 1. & 870 & 10 & 900 \\
2. & 870 & 12.5 & 900 \\
3. & 870 & 14 & 900 \\
\hline
\end{tabular}

Pengujian spesimen dilakukan sepanjang 2 inch dan diuji 1/16 bagian, posisi pengujian dapat dilihat pada gambar 2.

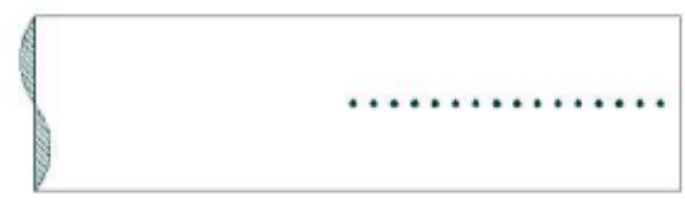

Gambar 2. Titik Pengujian Spesimen

Pengujian kekerasan dilakukan dengan metode Rockwell, dengan prosedur mula-mula indentor ditekan ke permukaan logam yang diuji dengan beban awal (minor load) sebesar $10 \mathrm{kgf}$, setelah itu penekanan indentor diteruskan dengan beban utama (mayor load) selama beberapa saat sampai proses pembebanan kembali ke beban awal. Metode pengujian Rockwell dapat dilihat pada gambar 3 .

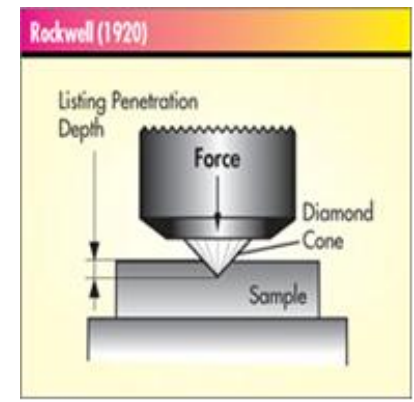

Gambar 3. Pengujian Rockwell [9]

\section{Hasil dan Pembahasan}

Sebelum dilakukan uji jominy, benda uji dipanaskan terlebih dahulu didalam tanur (dapur pemanas) yang bertujuan untuk memperbaiki sifat-sifat dari material baja. Proses heat treatment pada masing masing spesimen dilakukan pada temperatur $780^{\circ} \mathrm{C}$ dengan holding time 90 menit. Spesifikasi dan gambar tanur masing-masing dapat dilihat pada Tabel 2 dan Gambar 4.

Tabel 2. Spesifikasi Tanur

\begin{tabular}{|c|c|}
\hline Type & B-150 \\
\hline Model & N 17 / HR \\
\hline Year & 2009 \\
\hline Tmin-Tmax & $30^{\circ} \mathrm{C}-1280^{\circ} \mathrm{C}$ \\
\hline Volt & 400 \\
\hline Frekuenzy & $50 / 60 \mathrm{~Hz}$ \\
\hline
\end{tabular}




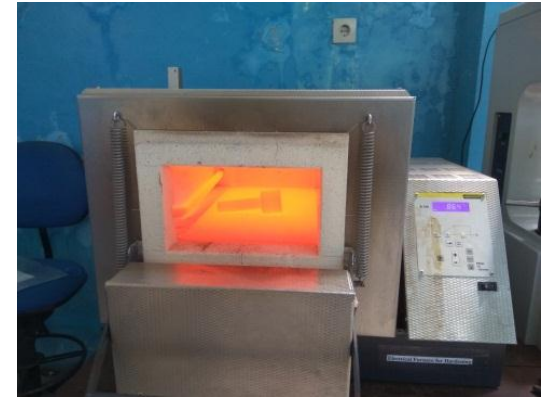

Gambar 4. Proses Heat Treatment

Setelah proses pemanasan selesai, spesimen dikeluarkan dengan cepat dari dalam tanur (waktu mengeluarkan spesimen dari dalam tanur \pm 1 menit) kemudian dilakukan proses pendinginan pada alat Jominy test. Spesimen uji digantungkan pada peralatan quench dan kemudian salah satu ujungnya dicelupkan dengan cepat pada air yang bertemperatur $25^{\circ} \mathrm{C}$. Diameter dari berkas air yang dipancarkan kira-kira $12 \mathrm{~mm}$ dan harus memancar $65 \mathrm{~mm}$ dari ujung nozzle. Proses pendinginan dapat dilihat pada Gambar 5.

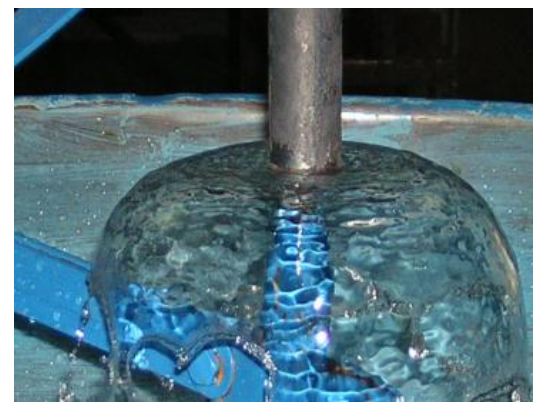

Gambar 5. Proses pendinginan pada alat uji jominy

Hasil pengujian kemampukerasan dari masing-masing spesimen pada proses heat treatmanet dengan temperatur $870{ }^{\circ} \mathrm{C}$ dan holding time 90 menit, kemudian didinginkan dengan cepat pada alat uji jominy selama 15 menit. Adapun perlakukan yang dilakukan pada saat proses pendinginan yaitu memvariasikan jarak nozzle penyemprot terhadap ujung benda uji. Hasil pengujian disajikan Gambar 6.

Terdapat peningkatan nilai kekerasan antara sebelum dilakukan perlakukan panas dan sesudah dilakukan perlakuan panas dengan proses pendinginan Jominy Test. Terdapat 3 buah spesimen yang akan diuji nilai kemampukerasannya dengan memvariasikan jarak nozzle penyemprot terhadap ujung benda uji yaitu $10 \mathrm{~mm}, 12.5 \mathrm{~mm}$, dan $14 \mathrm{~mm}$ dengan waktu penyemprotan 15 menit pada temperatur pemasasan $780{ }^{\circ} \mathrm{C}$ sedangkan lama holding time 90 menit. Nilai kekerasan rata-rata sebelum perlakuan panas sebesar $43.81 \mathrm{kgf}$. Setelah dilakukan perlakuan panas dengan proses pendinginan meggunakan Jominy test, didapat nilai kekerasan rata-rata masing-masing spesimen sebagai berikut: spesimen satu dengan jarak nozzle terhadap ujung spesimen $10 \mathrm{~mm}$ nilai kekerasan HRB sebesar $45.43 \mathrm{kgf}$, pada spesimen dua dengan jarak nozzle terhadap ujung spesimen $12.5 \mathrm{~mm}$ nilai kekerasan HRB sebesar $45.68 \mathrm{kgf}$ dan spesimen tiga dengan jarak nozzle terhadap ujung spesimen 14 mm nilai kekerasan HRB sebesar 44.31 kgf.

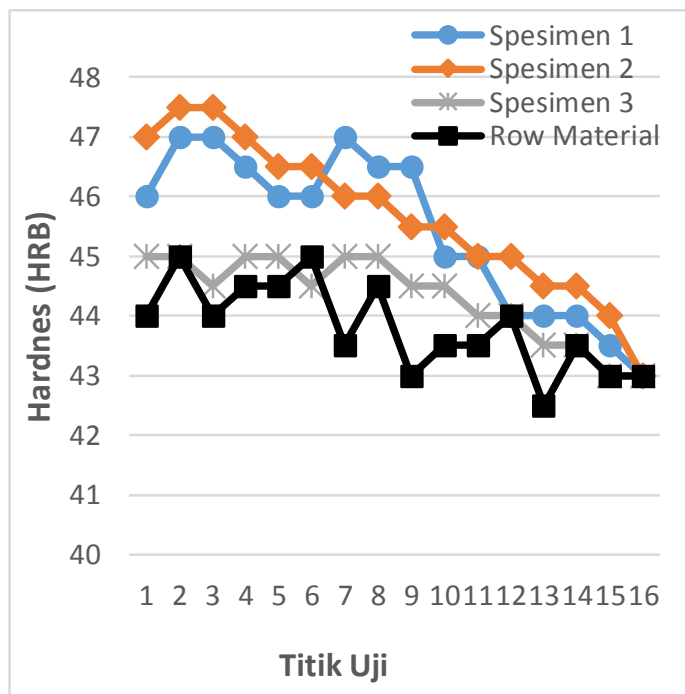

Gambar 6. Grafik perbandingan kemampu kerasan spesimen

Pada gambar 6 terlihat perbandingan nilai kekerasan baja komersil dengan variasi jarak nozzle penyemprot terhadap ujung spesimen bagian bawah. Dimana pada jarak penyemprotan $10 \mathrm{~mm}$ nilai kekerasan tertinggi sebesar $47 \mathrm{kgf}$ dan nilai kekerasan terendah $43 \mathrm{kgf}$, pada jarak penyemprotan $12.5 \mathrm{~mm}$ nilai kekerasan tertinggi sebesar $47.5 \mathrm{kgf}$ dan nilai kekerasan terendah $44 \mathrm{kgf}$, dan pada jarak penyemprotan $14 \mathrm{~mm}$ nilai kekerasan 
tertinggi sebesar $45 \mathrm{kgf}$ dan nilai kekerasan terendah $43 \mathrm{kgf}$, sedangkan nilai kekerasan spesimen sebelum dilakukan perlakuan panas sebesar $45 \mathrm{kgf}$.

Jika dilihat dari kenaikan nilai kekerasan rata-rata pada jarak penyemprotan $10 \mathrm{~mm}$ terhadap spesimen sebelum dilakukan perlakuan panas, terjadi peningkatan nilai kekerasan sebesar 1.62 kgf, begitu juga pada jarak penyemprotan $12.5 \mathrm{~mm}$ kenaikan kekerasan rata-rata sebesar $1.87 \mathrm{kgf}$ dan pada jarak penyemprotan $14 \mathrm{~mm}$ kenaikan kekerasan rata-rata sebesar $0.5 \mathrm{kgf}$. Peningkatan nilai kekerasan spesimen sebelum dilakukan perlakuan panas dengan yang dilakukan perlakuan panas tidak begitu signifikan. Spesimen satu mengalami peningkatan sebesar $3.56 \%$, spesimen dua mengalami peningkatan sebesar $4.02 \%$ dan spesimen tiga mengalami peningkatan $1.12 \%$.

\section{Kesimpulan}

Dari hasil pengujian pengaruh jarak nozzle penyemprot terhadap kemampukerasan material baja komersil, dapat disimpulkaan bahwa nilai kekerasan tertinggi terdapat pada bagian yang paling dekat dengan nozzle penyemprot. Peningkatan nilai kekerasan sebesar $3.56 \%$ pada spesimen satu, $4.02 \%$ pada spesimen dua dan $1.12 \%$ pada spesimen tiga.

Nilai kemampu kerasan baja sangat dipengaruhi oleh kandungan karbon dalam strusktur baja tersebut. Tidak semua jenis baja dapat dikeraskan secara langsung. Proses pengerasan secara langsung hanya dapat dilakukan pada baja dengan kadar karbon diatas $0.3 \%$.

\section{Referensi}

[1] Surdia, T., 1989. Pengetahuan Bahan Teknik, PT. Pradnya Paramita, Jakarta.

[2] Edy Purwanto, R., Anggit Murdani., Nurchajat., 2016. Teknologi Bahan, Polinema Press, Malang.
[3] Sutowo, C. et al, 2013. Pengaruh proses Hardenaility pada baja HQ 7 AISI 4140 dengan media Oli dan Air terhadap sifat Mekanis dan Struktur Mikro. SINTEK 7, 58-69.

[4] Yusuf., Chandra, Y., 2018. Pengaruh Variasi Holding Time Terhadap Kemampukerasan Baja Menggunakan Alat Uji Jominy. INOVTEK POLBENG 8, NO.2, 257262.

[5] Van Vlack, L.H., 1991. Ilmu dan Teknologi Bahan alih Bahasa Sriati Djaprie, $5^{\text {rd }}$ ED., Erlangga, Jakarta.

[6] Parker, E.R., 1967, Materials Data Book, Mc Graw-Hill Book Company, New york.

[7] Harjuma., Parekke, S., 2019,. Analisis Pengaruh Variasi Temperatur Baja AISI 1018 Terhadap Kekerasan Dengan Metode Jominy Test. Dinamika 10, NO.2, 53-58

[8] Rokhman, T., 2015. Perancangan Alat Uji Kemampu Kerasan Jominy Test untuk Laboratorium Teknik Mesin Universitas Islam 45 Bekasi. Jurnal Ilmiah Teknik Mesin 3, No. 10, 68-80.

[9] B. S. Nasional, 1989, SNI Cara Uji Keras Rockwell.

[10] Schonmetz, Gruber. 1985. Pengetahuan Bahan dalam Pengerjaan Logam. Terjemahan Eddy D. Hardjapamekas, Angkasa, Bandung. 